\title{
PENGUJIAN PENGARUH TETUA BETINA TERHADAP SIFAT TOLERANSI PADA NAUNGAN KEDELAI [Glycine max (L.) Merill]
}

\author{
TITIN HANDAYANI \\ Balai Teknologi Lingkungan-Badan Pengkajian dan Penerapan Teknologi \\ PUSPIPTEK Serpong Tangerang Banten
}

\begin{abstract}
This study was conducted at Green House IPB Cikabayan Darmaga Research Station. Soybean tolerance genotype (Ceneng) was crossed with sensitive genotype (Godek A) to study the mode of inheritance in tolerance to shade. Reciprocal cross were also made in soybean Ceneng and Godek A to study maternal effect. This experiment was conducted under artificial shading by using paranet with light intensity $75 \%$. Material genetic were used Ceneng, Godek $A, F_{1}$ and $F_{1}$ ' that were planted according to complete Randomized Experimental Design. The result of " $\mathrm{t}$ " test showed that anatomical, morphological characters, and molecular marker for tolerance and sensitive genotype was significant difference, while was no significant in $F_{1}$ and $F_{1}$ '. This experiment can be concluded that there was no maternal effect found in the soybean crossing between tolerance and sensitive genotype.
\end{abstract}

Key words : soybean, shading, maternal effect

\section{PENDAHULUAN}

Kemampuan tanaman untuk beradaptasi terhadap kondisi lingkungan spesifik akan ditentukan oleh sifat genetik tanaman (Mohr dan Schoopfer, 1995). Ketersediaan keragaman genetik akan menentukan keberhasilan program pemuliaan untuk toleransi terhadap naungan. Namun hal ini perlu ditunjang oleh pengetahuan mengenai pola pewarisan sifatnya. Sampai saat ini informasi tentang genetik dan pewarisan sifat toleransi terhadap naungan masih sangat kurang.

$$
\text { Menurut Austin (1993) karakter }
$$
morfologi, seperti tinggi tanaman, ukuran daun, bentuk kanopi tanaman, secara relatif mudah diidentifikasi dan dihitung, tidak berubah dalam waktu singkat dan heritabilitasnya tinggi. Oleh karena itu karakter tersebut paling sering digunakan oleh pemulia tanaman dalam studi pewarisan sifat. Sifat morfologi tanaman umumnya dikendalikan secara genetik, sehingga berpeluang untuk dimanipulasi. Hal ini dimungkinkan karena sifat morfologi ini mempunyai nilai heritabilitas yang tinggi. Namun menurut Caccarelli (1994) heritabilitas pada lingkungan rawan cekaman abiotik pada umumnya lebih rendah dibandingkan pada lingkungan optimum.

Kalau kita menengok kembali percobaan yang dilakukan oleh Mendel, pewarisan sifat kualitatif yang dipelajari pada zuriat hasil persilangan identik dengan zuriat hasil persilangan resiprokalnya. Akan tetapi dalam beberapa kejadian dilaporkan bahwa zuriat yang dihasilkan dari persilangan resiprokalnya menyerupai tetua betinanya. Dalam persilangan, tetua betina memberikan sitoplasma dan setengah genomnya kepada zuriat hasil zigot, jadi ada petunjuk bahwa terdapat pewarisan sitoplasmik atau plastid. Pewarisan yang dikontrol oleh gen yang ada di luar inti disebut pewarisan ekstranuklear atau ekstra kromosomal (Hartana, 1992).

Penelitian padi gogo pada naunga dilaporkan bahwa tidak ada pewarisan sifat toleransi terhadap naungan yang dipengaruhi oleh tetua betinanya (Junaedi et.al., 1999; Sahardi et.al., 2000). Pada tanaman kedelai telah dilaporkan oleh Rostini et.al. (2000), bahwa tidak ada pengaruh tetua betina pada pewarisan sifat kandungan klorofil maksimum, tetapi ada pengaruh tetua betina pada periode lama kandungan klorofil maksimum dan retensi klorofil maksimum.

Penelitian ini bertujuan untuk mempelajari pewarisan sifat toleransi terhadap intensitas cahaya rendah pada pada zuriat hasil persilangan kedelai toleran (Ceneng) dengan peka (Godek A) dan resiprokalnya. Karakter yang diamati adalah karakter yang telah dianalisis pada penelitian sebelumnya yaitu karakter klorofil $a$ dan jumlah cabang produktif yang terkait dengan toleransi terhadap intensitas cahaya rendah. Hipotesis yang diajukan adalah bahwa tidak ada pengaruh tetua betina pada pewarisan sifat klorofil $a$ dan jumlah cabang produktif. 


\section{METODOLOGI PENELITIAN}

\section{Persilangan antara Tetua Terpilih}

Tetua terpilih ditentukan dari hasil seleksi terhadap intensitas cahaya rendah yang dilakukan pada percobaan sebelumnya yang merupakan uji ulang dari penelitian Elfarisna et al., 2000. Persilangan dilakukan antara tetua toleran yaitu genotipe Ceneng dengan tetua peka yaitu genotipe Godek A dan resiproknya untuk memperoleh bahan kegenetikaan yang digunakan dalam studi identifikasi sifat anatomi, morfologi dan molekuler. Persilangan ini dilakukan di Rumah Plastik Balai Teknologi Lingkungan - BPPT PUSPIPTEK Serpong Tangerang.

\section{Pengaruh Tetua Betina}

Sebagai bagian dari studi pewarisan sifat, dilakukan pengujian terhadap populasi $F_{1}$ dan resiprokalnya untuk mengetahui pengaruh tetua betina pada pewarisan sifat toleransi terhadap intensitas cahaya rendah.

Penelitian dilakukan di KP IPB Cikabayan pada bulan Juli sampai September 2002. Pengujian dengan menggunakan naungan $0 \%$ dan $75 \%$.

Bahan kegenetikaan yang digunakan adalah varietas Ceneng sebagai tetua toleran, Godek A sebagai tetua peka, $\mathrm{F}_{1}$ dan resiproknya. Penanaman benih tetua dan zuriatnya menggunakan polibag berukuran 40 x $40 \mathrm{~cm}$. Rancangan lingkungannya adalah Rancangan Acak Kelompok dengan dua ulangan. Setiap kelompok ditanam sebanyak 10 tanaman untuk masing-masing tetua dan zuriatnya. Pengujian menggunakan Rancangan Petak Terpisah.

Peubah yang diamati adalah tinggi tanaman, jumlah cabang, kandungan karoten, klorofil $a$ dan $b$ serta jumlah polong bernas. Analisis pengaruh tetua betina dalam pewarisan sifat toleransi terhadap intensitas cahaya rendah, nilai tengah dari populasi $F_{1}$ dan resiprokalnya dibandingkan dengan uji " $\mathrm{t}$ " menurut Singh dan Chaudary (1979). Perbedaan yang nyata diantara nilai tengah populasi $F_{1}$ dan resiprokalnya, menunjukkan adanya pengaruh tetua betina.

Tanaman $\mathrm{F}_{1}$ yang diperoleh dari hasil persilangan kemudian ditanam dan sebagian dibiarkan bersari sendiri, sedangkan sebagian yang lain disilang balikkan kepada kedua tetuanya untuk memperoleh generasi silang balik $\mathrm{BC}_{1} \mathrm{P}_{1}$ dan $\mathrm{BC}_{1} \mathrm{P}_{2}$. Sehingga diperoleh seluruh generasi yang diperlukan untuk melakukan identifikasi sifat toleransi terhadap intensitas rendah yaitu $\mathrm{P}_{1}, \mathrm{P}_{2}, \mathrm{~F}_{1}$, $\mathrm{F}_{1}$ resiprok, $\mathrm{F}_{2}, \mathrm{BC}_{1} \mathrm{P}_{1}$ dan $\mathrm{BC}_{1} \mathrm{P}_{2}$.

\section{Analisis Molekuler AFLP}

Analisis AFLP dilakukan pada tetua toleran (Ceneng), tetua peka (Godek $\mathrm{A}), \mathrm{F}_{1}, \mathrm{~F}_{1}$, populasi $\mathrm{F}_{2}, \mathrm{BC}_{1} \mathrm{P}_{1}$ dan $\mathrm{BC}_{1} \mathrm{P}_{2}$ terdiri dari dua tahap. Tahap pertama yaitu seleksi kombinasi primer dengan menggunakan DNA tetua. Primerprimer yang digunakan adalah primer yang memberikan polimorfik terhadap tetua toleran (Ceneng) dan peka (Godek A). Analisis tahap kedua dilakukan melalui metoda BSA (Bulk Segregation Analysis). Terdapat 10 kelompok DNA untuk famili persilangan, yaitu (1) DNA tetua peka; (2) DNA tetua toleran, (3) DNA $F_{1}$; (4) DNA $F_{1}$ resiproknya; (5) Bulk toleran terdiri atas campuran DNA preamplified dari individu-individu tanaman yang sangat toleran dalam populasi $\mathrm{BC}_{1} \mathrm{P}_{1}$; (6) Bulk peka terdiri atas campuran DNA preamplified dari individu-individu tanaman yang sangat peka dalam populasi $\mathrm{BC}_{1} \mathrm{P}_{1}$; (7) Bulk toleran terdiri atas campuran DNA preamplified dari individu-individu tanaman yang sangat toleran dalam populasi $\mathrm{BC}_{1} \mathrm{P}_{2}$; (8) Bulk peka terdiri atas campuran DNA preamplified dari individu-individu tanaman yang sangat peka dalam populasi $\mathrm{BC}_{1} \mathrm{P}_{2} ;$; (9) Bulk toleran terdiri atas campuran DNA preamplified dari individu-individu tanaman yang sangat toleran dalam populasi $F_{2}$. Analisis molekuler AFLP dilakukan di Laboratorium Molekuler 'Technical University of Muenchen" Freising-Germany.

\section{Isolasi dan Pemurnian DNA}

DNA genomik diekstraksi dari daun tanaman berumur 2 minggu yang ditumbuhkan di dalam kondisi naungan. Ekstraksi DNA menggunakan metode CTAB (Saghai-Maroof et al., 1984).

\section{Tahapan Analisis}

Analisis AFLP dilakukan sesuai dengan AFLP plant mapping kit dari PE/Applied Biosystems. Ada tiga tahapan yang harus dilakukan yaitu sebagai berikut.

\section{(a). Restriksi-Ligasi}

DNA genom sebanyak $0,5 \mu \mathrm{g}$ dipotong dengan $1 \mathrm{U}$ MseI dan $5 \mathrm{U}$ EcoRI dan pada saat yang sama 5 pmol adaptor EcoRI dan $50 \mathrm{pmol}$ adaptor MseI diligasi dengan $1 \mathrm{U}$ T4 DNA ligase (New England Biolabs, Beverly, MA, VSA) pada suatu bufer yang mengandung $10 \mathrm{mM}$ Tris- $\mathrm{HCl}$ (pH 7,8), $1 \mathrm{mM} \mathrm{MgCl}$, $1 \mathrm{mM}$ DTT, 0,1 mM ATP, $50 \mathrm{mM} \mathrm{NaCl}_{2}$ dan $50 \mathrm{ng} / \mu$ l bovine serum albumin dalam volume total $11 \mu \mathrm{l}$ selama 2 jam pada $37^{\circ} \mathrm{C}$. 


\section{(b). Pre-amplifikasi}

Sampel hasil restriksi-ligasi kemudian dilarutkan dengan $189 \mu \mathrm{l} \mathrm{H}_{2} \mathrm{O}$ untuk menghasilkan konsentrasi yang sesuai untuk reaksi PCR selanjutnya. Preselektif amplifikasi dari sequen target ditingkatkan fragmennya sesuai dengan yang diinginkan dengan primer homologous-adaptor EcoRI dan MseI yang masing-masing memiliki satu nukleotida tambahan pada ujung $3^{\prime}$. Reaksi PCR akan dilakukan dengan $4 \mu \mathrm{l}$ hasil dilusi restriksiligasi; $0,125 \mu \mathrm{M} E c o \mathrm{RI}+1$ primer; $0,25 \mu \mathrm{M}$ MseI; 0,4 unit DNA Tag polimerase (Qiagen $\mathrm{GmbH}$, Germany); 0,2 mM setiap dNTP (AmershamPharmacia Biotech, Uppsala, Sweden) dan $1 \mathrm{x}$ Qiagen buffer PCR dengan volume total $20 \mu \mathrm{l}$. Amplifikasi siklus yang digunakan adalah 20 siklus yang terdiri dari 10 detik denaturasi pada $94{ }^{\circ} \mathrm{C}, 30$ detik annealing pada $60{ }^{\circ} \mathrm{C}$ dan 2 menit ekstensi pada $72{ }^{\circ} \mathrm{C}$. Verifikasi amplifikasi yang berhasil, 10 $\mu \mathrm{l}$ reaksi PCR dipisahkan dengan gel agarose 1,5 $\%$; hasil smear dari fragmen target amplifikasi harus terlihat pada kisaran 1000-1500 bp. Sisa yang $10 \mu$ dilarutkan 20 kali dengan menambahkan 190 $\mu \mathrm{l} \mathrm{H}_{2} \mathrm{O}$ dan disimpan pada $4{ }^{\circ} \mathrm{C}$.

\section{(c). Amplifikasi Selektif}

Pada tahap amplifikasi selektif ini dilakukan dengan primer EcoRI dan MseI yang memiliki tiga nukleotida tambahan. Analisis fragmen multifluorophore, EcoRI dilabel dengan 5carboxy-fluorescein (5-FAM); $2^{1}, 7^{1}$ - dimethoxy$4^{1}, 5^{1}$ dichloro-6-carboxy-fluorescein (JOE), atau $\mathrm{N}, \mathrm{N}, \mathrm{N}^{1}, \mathrm{~N}^{1}-\quad$ tetramethyl-6-carboxyrhodamin (TAMRA), sedangkan primer MseI tidak dilabel.

Reaksi PCR dilakukan dengan menggunakan $3 \mu \mathrm{l}$ hasil dilusi pre-amplifikasi; 0,05 $\mu \mathrm{M} E c o \mathrm{RI}+3$ primer; $0,25 \mu \mathrm{M} \mathrm{MseI}+3$ primer; 0.4 DNA Tag polimerase; masing-masing dNTP dan 1x Qiagen buffer PCR dalam volume $20 \mu \mathrm{l}$. Selektivitas'yang tinggi diperoleh melalui siklus berikut: satu siklus yang terdiri dari 30 detik pada $94{ }^{\circ} \mathrm{C}, 30$ detik pada $65{ }^{\circ} \mathrm{C}, 2$ menit pada $72{ }^{\circ} \mathrm{C}$ diikuti oleh 8 siklus yang terdiri dari penurunan temperatur annealing $1{ }^{\circ} \mathrm{C}$ per siklus dan akhirnya 23 siklus yang terdiri dari 1 detik pada $94{ }^{\circ} \mathrm{C}, 30$ detik pada $65^{\circ} \mathrm{C}, 2$ menit pada $72{ }^{\circ} \mathrm{C}$. Semua reaksi PCR dilakukan dengan Perkin Elmer 9600 thermocycler (PE/Applied Biosystems, Foster City, CA, USA).
Analisis multifluorophore campuran 0,4 $\mu \mathrm{l}$ dari hasil PCR yang dilabel 5-FAM; $0, .5 \mu \mathrm{l}$ hasil PCR yang dilabel JOE atau $0,7 \mu l$ hasil PCR yang dilabel TAMRA. Sampel kombinasi ini dicampur dengan $0.2 \mu \mathrm{l}$ internal length standard genescan500 ROX (PE/Applied Biosystem) yang dilabel dengan 6-carboxy-X-rhodamin (ROX) dan 0,8 $\mu \mathrm{l}$ pewarna formamid ( $98 \%$ formamide, $0,005 \%$ dextran blue), didenaturasi selama 3 menit pada 90 ${ }^{\circ} \mathrm{C}$ dan dengan cepat didinginkan pada es. Elektroforesis dilakukan dengan menggunakan $5 \%$ denaturing polyacrilamide gels (Long Ranger ${ }^{\mathrm{TM}}$, FMC Bioproducts, Rockland, ME, USA) dengan buffer elektroforesis TBE 1x ( $89 \mathrm{mM}$ Tris-base, 89 $\mathrm{mM}$ asam borat, 2,0 mM EDTA, $\mathrm{pH} 8,3$ ) pada ABI Prism $^{\mathrm{TM}} 377$ DNA sequencer (PE/Applied Biosystems) pada $2500 \mathrm{~V}$ selama 4 jam. $A B I$ collection software versi 1.1 digunakan untuk mengumpulkan data.

\section{HASIL DAN PEMBAHASAN}

\section{Persilangan antara Tetua Terpilih}

Tetua terpilih adalah genotipe Ceneng sebagai tetua toleran dan genotipe Godek A sebagai tetua peka dengan pertimbangan perubahan hasil relatif yang menunjukkan sifat paling toleran diantara genotipe yang diuji adalah genotipe Ceneng, sedangkan genotipe paling peka adalah Godek A.

Genotipe Ceneng adalah kedelai berwarna hitam dan genotipe Godek $\mathrm{A}$ adalah kedelai berwarna kuning, Keunggulan kedelai Godek A adalah mempunyai daya hasil tinggi, sedangkan Ceneng belum diketahui keunggulannya selain toleran terhadap naungan.

\section{Pengaruh Tetua Betina}

Kedua tetua , $F_{1}$ dan $F_{1}$ resiproknya (Gambar 1 dan 2) diuji pada naungan $75 \%$ untuk diamati ada atau tidak pengaruh tetua betina. Tanaman $F_{1}$ dan $F_{1}$ resiproknya dari persilangan kedua genotipe tersebut mempunyai karakter warna kedelai hijau kekuningan (Gambar 3). Hal ini menunjukkan bahwa warna kedelai dari tetua 1 tidak dominan terhadap tetua 2 dan sebaliknya. 


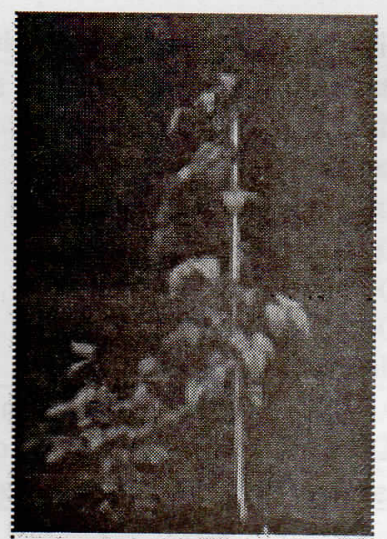

Ceneng

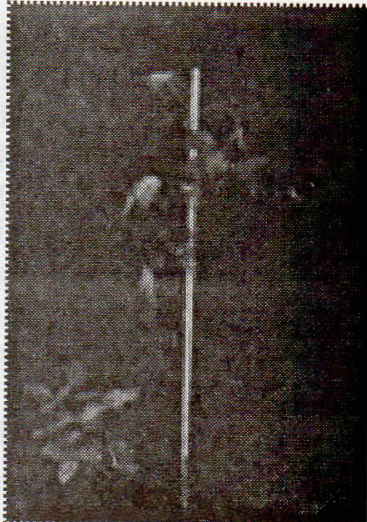

Godek A

Gambar 1. Ceneng dan Godek A dengan perlakuan naungan $0 \%$ dan $75 \%$, perlakuan naungan $75 \%$ mengalami etiolasi

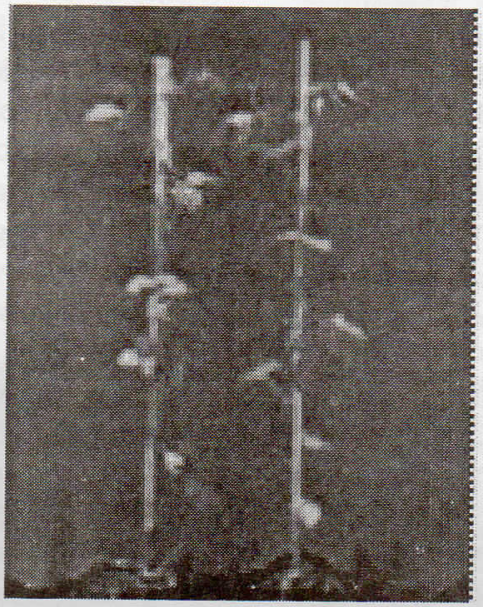

Gambar 2. Penampilan $F_{1}$ Ceneng $x$ Godek $A$ dan $F_{1}$ resiproknya dengan perlakuan naungan $75 \%$.

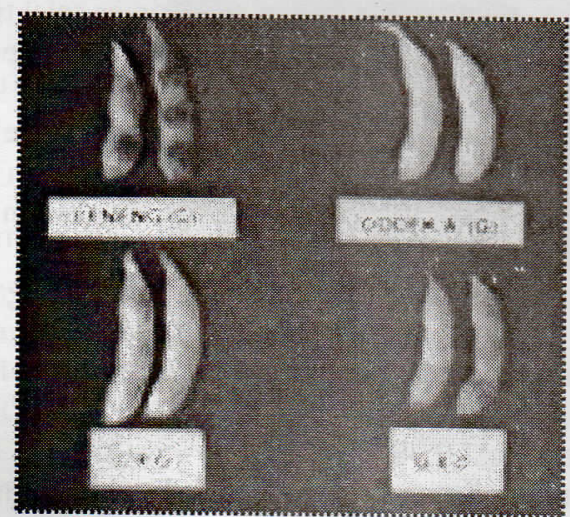

(a)

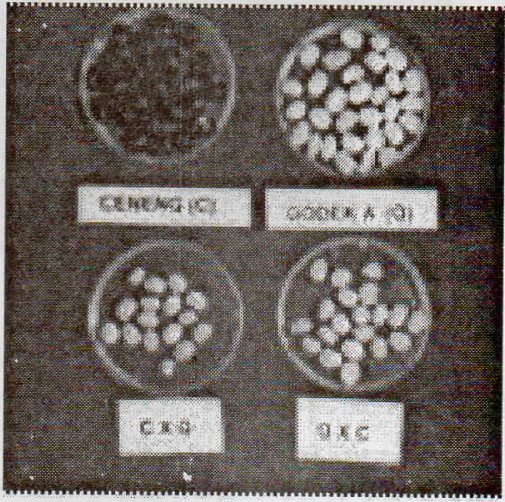

(b)

Gambar 3. Biji Kedelai Ceneng, Godek A, F1 (a) dan resiproknya (b). 
Berdasarkan uji-t yang dilakukan menurut Singh dan Chaudhary (1979) yang ditampilkan pada Tabel 1 menunjukkan bahwa ' $t$ ' hitung lebih kecil dari pada ' $t$ ' tabel dengan derajat bebas efektif sesuai dengan keragaman yang ada untuk semua karakter yang diamati, kecuali penguningan daun. Hal ini menunjukkan bahwa tidak ada perbedaan nilai antara populasi tanaman $F_{1}$ dengan populasi tanaman $\mathrm{F}_{1}$ resiproknya untuk semua karakter yang diamati, kecuali penguningan daun atau senesens. Berarti tidak ada gen diluar inti yang mempengaruhi pewarisan sifat pada kedelai toleran dan peka terhadap naungan.

Tabel 1. Hasil Uji-T Dari Persilangan Genotipe Ceneng Dan Godek A Berikut Resiproknya

\begin{tabular}{lccccccc}
\hline \multicolumn{1}{c}{ Karakter } & $\begin{array}{c}\mathrm{P}_{1} \\
\text { Ceneng } \\
(\mathrm{C})\end{array}$ & $\begin{array}{c}\mathrm{P}_{2} \\
\mathrm{Godek} A \\
(\mathrm{G})\end{array}$ & $\begin{array}{c}\mathrm{t} \text {-hitung } \\
\mathrm{P}_{1} \text { dan } \mathrm{P}_{2}\end{array}$ & $\begin{array}{c}\mathrm{F}_{1} \\
(\mathrm{C} \times \mathrm{G})\end{array}$ & $\begin{array}{c}\mathrm{F}_{1} \text { resiprok } \\
(\mathrm{G} \times \mathrm{C})\end{array}$ & $\begin{array}{c}\mathrm{t} \text {-hitung } \\
\mathrm{F}_{1} \text { dan } \mathrm{F}_{1} \\
\text { resiprok }\end{array}$ & $\begin{array}{c}\mathrm{t} \text {-tabel } \\
0,05\end{array}$ \\
\hline $\begin{array}{l}\text { Anatomi: } \\
\text { Klorofil } a(\mathrm{mg} / \mathrm{g})\end{array}$ & 1,5216 & 1,3516 & $21,7948^{*}$ & 1,4103 & 1,4108 & 0,0072 & 2,101 \\
$\begin{array}{l}\text { Morfologi: } \\
\begin{array}{l}\text { Jumlah cabang } \\
\text { produktif }\end{array}\end{array}$ & 4,1 & 3,1 & $245,753^{*}$ & 4,05 & 4,0 & 0,2251 \\
\hline
\end{tabular}

Sumber data : Analisis data primer

Pewarisan sifat kandungan klorofil yang dilakukan oleh Rostini et al. (2000) dilaporkan bahwa hasil uji-t antara $F_{1}$ dengan $F_{1}$ resiproknya tidak ada perbedaan nyata untuk karakter kandungan klorofil maksimum $\left(\mathrm{K}_{\text {maks }}\right)$. Tetapi ada perbedaan pada karakter lama klorofil maksimum $\left(\mathrm{Lk}_{\mathrm{maks}}\right)$ dan retensi klorofil maksimum $\left(\mathrm{RK}_{\text {maks }}\right)$. Dengan demikian menunjukkan bahwa kedua karakter klorofil tersebut dikendalikan oleh gen pada sitoplasma. Lamanya klorofil maksimum menunjukkan karakter klorofil daun yang masa hidupnya lama atau proses degradasinya lambat. Adanya pengaruh sitoplasma pada proses penguningan daun sejalan dengan penelitian Guaimet et al. (1990) yang menyebutkan adanya pengaruh gen $C y t G$ terhadap penguningan daun selain adanya pengaruh gen inti. Suatu karakter dapat dikendalikan oleh gen di dalam inti saja atau gen sitoplasma saja atau oleh keduanya. Untuk memastikan ada tidaknya pengaruh gen inti selain sitoplasma dapat dilihat pada generasi $\mathrm{F}_{2}$.

\section{Analisis Molekuler AFLP}

Teknologi AFLP dapat digunakan untuk membuat peta keterkaitan kedelai melalui penghitungan dari penampakan dua marka fragmen AFLP yang diturunkan bersama dalam populasi. Dalam segregasi populasi yang dihasilkan dari persilangan antara dua galur tetua. Keturunan yang dihasilkan dari persilangan ini adalah generasi pertama atau $F_{1}$. Tanaman $F_{1}$ mempunyai semua pita DNA dari kedua tetuanya. Pita-pita tersebut mungkin ada dalam satu copy, jika hanya satu tetua yang mempunyai pita; atau dua copy jika kedua tetua mempunyai pita

Analisis AFLP pada penelitian ini digunakan 3 kombinasi primer ( Tabel 2), diantaranya kombinasi primer selektif EcoRI-AGT/ MseI-CAC menghasilkan marka spesifik fragmen 130 pasangan basa. Pada Gambar 19 menunjukkan segregasi pita DNA pada sebuah gel elektriforesis. Pita-pita DNA berwarna biru dan DNA standar berwarna merah. Sistem deteksi multifluorophore dengan menggunakan ABIPrism ${ }^{\mathrm{TM}} 377$ DNA sequencer memudahkan analisis tiga sampel DNA yang dilabel dengan pewarna fluoroscence yang berbeda. 
Tabel 2. Sequen Nukleotida Dari Adaptor Dan Primer Selektif Yang Digunakan Dalam Penelitian Ini

\begin{tabular}{lll}
\hline Adapter & MseI & 5'-GACGATGATCCTGAG-3' \\
& & 3'-TACTCAGGACTCAT-5' \\
& 5'-CTCGTAGACTGCGTACC-3' \\
\multirow{3}{*}{ MseI } & EcoRI & 3'-CTGACGCATGGTTAA-5' \\
& M1 & 5'-GATGAGTCCTGAGTAA-AGT-3' \\
\multirow{4}{*}{ EcoRI } & M2 & 5'-GATGAGTCCTGAGTAA-AGG-3' \\
& M3 & 5'-GATGAGTCCTGAGTAA-AGC-3' \\
& M1 & 5'-ACTGCGTACCAATTC-ACT-3' \\
& M2 & 5'-ACTGCGTACCAATTC-CAC-3'
\end{tabular}

*) Primer selektif yang menghasilakan marker spesifik pada DNA genom kedelai toleran terhadap intensitas cahaya rendah.

Pengujian sistem deteksi dapat membedakan multimix reaksi AFLP, tiga sampel DNA dengan label 5-FAM, JOE atau TAMRA dapat dianalisis secara terpisah dalam semua kemungkinan kombinasi. Dengan demikian elektroferogram yang diperoleh dari perangkat Gene Scan ${ }^{T M}$ menunjukkan tidak ada perbedaan dalam mendeteksi puncak dalam observasi komigrasi fragmen menujukkan perbedaan warna sesuai dengan warna pita pada autoradiogram.

Dalam penelitian ini, satu lajur pada autoradiogram tampak dua warna yaitu warna biru (label 5-FAM) dari sampel DNA dan warna merah (label ROX size standard) dari DNA standar. Gambar 4 menunjukkan satu contoh hasil penelitian ini yaitu resolusi fragmen AFLP dalam rentang ukuran 60-600 pb. Frgamen-fragmen adalah hasil amplifikasi dari kombinasi primer selektif EcoRIAGT/ MseI-ACA menggunakan DNA genom kedelai Godek A sebagai cetakan: (A) Elektroferogram menunjukkan 41 puncak yang dapat dibedakan dari label fragmen AFLP 5-FAM. Skala vertikal menunjukkan signal relatif dari intensitas label fragmen fluorescen. Autoradiogram menunjukkan 41 fragmen AFLP yang dilabel dengan 5-FAM.

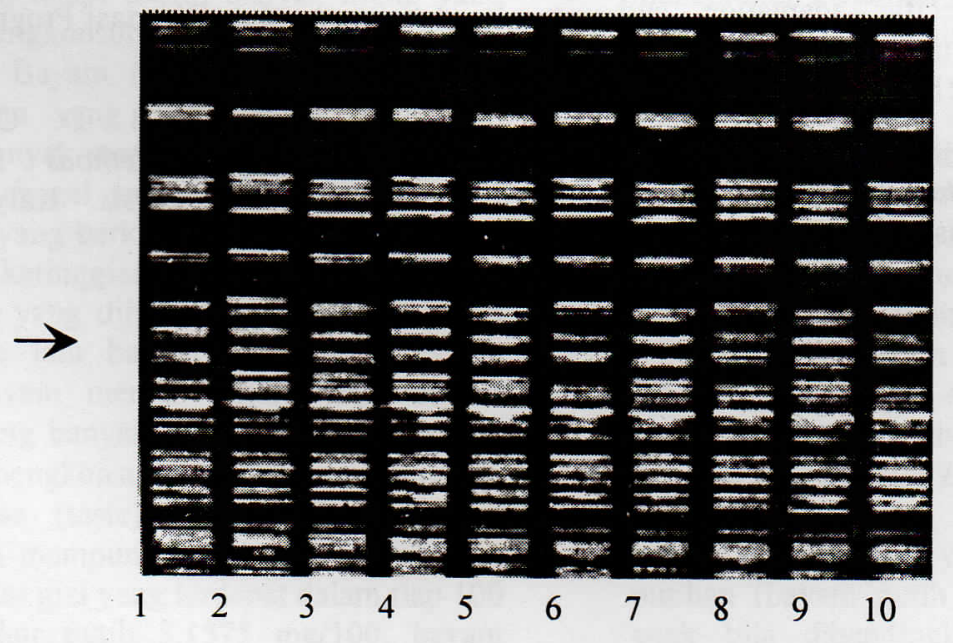

Gambar 4. Autoradiogram menunjukkan pita polimorfik yang dideteksi dengan teknik AFLP menggunakan primer selektif (EcoRI + AGT) dan (MseI +CAC), fragmen warna biru 1-10: Godek A (peka), Ceneng (toleran), $\mathrm{F}_{1}$ (Godek $\mathrm{A} x$ Ceneng), $\mathrm{F}_{1}$ resiproknya, $\mathrm{BCP}_{1}$ toleran, $\mathrm{BCP}_{1}$ peka, $\mathrm{BCP}_{2}$ toleran, $\mathrm{BCP}_{2}$ peka, $\mathrm{F}_{2}$ (Godek $\mathrm{A} \mathrm{x}$ Ceneng) toleran, $F_{2}$ peka. Lajur genotipe toleran menunjukkan marker spesifik 130 pasang basa (tanda panah). Fragmen warna merah adalah DNA standard (ROX), ukuran pasangan basa dari lajur paling bawah ke atas adalah $100 \mathrm{pb}, 125 \mathrm{pb}, 150 \mathrm{pb}$ dan $200 \mathrm{pb}$. 


\section{KESIMPULAN}

Persilangan dilakukan dengan tetua toleran, yaitu genotipe Ceneng dengan pertimbangan bahwa genotipe ini mempunyai keunggulan konsisten toleran terhadap intensitas cahaya rendah. Sedangkan tetua peka ditentukan genotipe Godek A dengan pertimbangan bahwa genotipe ini konsisten peka terhadap intensitas cahaya rendah dan mempunyai keunggulan produksi tinggi. Pengujian pengaruh tetua betina dengan uji ' $t$ ' untuk karakter anatomi klorofil $a$ dan karakter morfologi jumlah cabang produktif tidak menunjukkan perbedaan nyata. Tidak ditemukan perbedaan marka pada pita polomorfik DNA $F_{1}$ dan $\mathrm{F}_{1}$ ' yang dideteksi dengan teknik AFLP. Dengan demikian maka dalam percobaan selanjutnya dapat digunakan salah satu dari hibrid $F_{1}$ atau resiproknya.

\section{DAFTAR PUSTAKA}

Austin, R B. 1933. Augumenting yield-based selection. In: Plant Breeding: Principles and Prospect. M D Hayward, N O Bosemark and I Romagosa (Eds.) Chapmann and Hall, London.

Ceccarelli, S. 1994. Specific adaptation and breeding for marginal conditions. Euphytica 77:205-219.

Elfarisna. 2000. Adaptasi Kedelai terhadap Naungan: Studi Morfologi dan Anatomi. Tesis Magister Sains, Pascasarjana IPB.
Guaimet, J. J., J. A. Terri, and L. D. Nooden. 1990. Effects of nuclear and cytoplasmic genes altering chlorophyll loss on gas exchange during monocarpic senescence in soybean. Plant Cell Physiol. 31(8):1123-1130. Abstract.

Hartana, A. 1992. Genetika Tumbuhan. Dept. Pendidikan dan Kebudayaan. Dit Jend. Pendidikan Tinggi. PAU Ilmu Hayat. IPB.

Junaidi, S. Sastrosumarjo, D. Sopandie, dan Suwarno. 1999. Studi genetik pewarisan sifat toleransi naungan padi gogo (Oriza sativa L.). Tesis Magister Sains Program Pascasarjana IPB.

Mohr, H. and P. Scoopfer. 1995. Plant Physiology. Translated by Gudrun and D W Lawlor. Sprigner.

Rostini, N., A. Baihaki, R. Setiamihardja, dan G. Suryatmana. 2000. Pewarisan Karakter Kandungan Klorofil Pada Kedelai. Zuriat Vol. 11, No. 2. PERIPI. Fakultas Pertanian UNPAD. Sumedang, Jawa Barat.

Sahardi. 2000. Studi karakteristik anatomi dan morfologi serta pewarisan sifat toleransi terhadap naungan pada padi gogo (Oryza sativa L.). Disertasi Program Pascasarjana IPB.

Singh, R. K. and B. D. Chaudary. 1979. Biometrical Methods in Quantitative Genetics Analysis. Kalyani Publishers. New Delhi. 